\title{
Les débuts de la congélation dans les campagnes du nord-est de la France
}

L'expérience singulière des congélateurs collectifs

\section{Colette Méchin}

\section{(2) OpenEdition \\ Journals}

Édition électronique

URL : https://journals.openedition.org/tc/800

DOI : $10.4000 /$ tc. 800

ISSN : 1952-420X

\section{Éditeur}

Éditions de l'EHESS

Édition imprimée

Date de publication : 1 juin 1989

ISSN : 0248-6016

\section{Référence électronique}

Colette Méchin, "Les débuts de la congélation dans les campagnes du nord-est de la France »,

Techniques \& Culture [En ligne], 12। 1989, mis en ligne le 16 janvier 2006, consulté le 29 septembre 2022. URL : http://journals.openedition.org/tc/800 ; DOI : https://doi.org/10.4000/tc.800

Ce document a été généré automatiquement le 29 septembre 2022.

Tous droits réservés 
Les débuts de la congélation dans les campagnes du nord-est de la France

L'expérience singulière des congélateurs collectifs

Colette Méchin 